\title{
Botanical Description of Pigeonpea [Cajanus Cajan (L.) Millsp.]
}

\author{
C.V. Sameer Kumar, S.J. Satheesh Naik, Nidhi Mohan, \\ Rachit K. Saxena and Rajeev K. Varshney
}

\begin{abstract}
Pigeonpea [Cajanus cajan (L.) Millspaugh] is an important legume crop of the papilionaceae family. It is an often cross-pollinated crop, and breeding principles of both self and cross-pollinated crops are highly effective in its genetic enhancement. Pigeonpea is a hard woody shrub, extensively adaptable to a range of soil types, temperature, and rainfall. It has a deep taproot system extending up to two meters and can grow to a height of four meters. Pigeonpea roots form a symbiotic association with Brady rhizobium spp. and perform biological nitrogen fixation. The branching pattern of stem may vary from bush type to compact upright type and is of determinate, semi-determinate, and non-determinate type based on the flowering pattern. The primary leaves are simple, opposite, and caduceus, while the latter ones are pinnately trifoliate with lanceolate to elliptical leaflets. Pigeonpea flowers are zygomorphic, borne on terminal or auxiliary racemes and are normally yellow in color with some variations. It has ten stamens in diadelphous condition with light or dark yellow anthers. The ovary is superior with a long style attached to a thickened, incurved, and swollen stigma. Pigeonpea is an often cross-pollinated crop with an average of $20 \%$ cross-pollination. The fruit of pigeonpea is called pod, which is of various colors, with and without deep constrictions. Seeds (with $20-22 \%$ proteins and amino acids) can be round or lens shaped, in shades of white and brown color with yellow color cotyledon. Pigeonpea is a widely consumed multi-utility pulse crop, thus the knowledge about the crop botany is vital for modifying it according to future challenges and goals.
\end{abstract}

C.V. Sameer Kumar $(\bowtie)$ · R.K. Saxena · R.K. Varshney

Genetic Gains, International Crops Research Institute for the Semi-Arid Tropics (ICRISAT), Patancheru 502324 India

e-mail: c.sameerkumar@cgiar.org

\section{S.J. Satheesh Naik}

Pigeonpea Breeding, ICAR-IIPR, Kanpur, UP, India

N. Mohan

ANGRAU, Guntur, Andhra Pradesh, India 


\subsection{Introduction}

Cajanus cajan, commonly known as pigeonpea, is a multipurpose drought-tolerant crop cultivated mainly for its edible seeds which are high in dietary protein. It also has household importance and a number of medicinal uses. Apart from human consumption, it is also used as forage, feed, and meal for animals, piggery, and fishery. Cajanus cajan is a natural barrier for soil erosion and biological factory for fixing atmospheric nitrogen in soil. Globally, it is grown in more than 80 countries but it is an important grain legume in Asia (India and Myanmar) and Eastern and Southern Africa (Kenya, Tanzania, Malawi, Uganda, and Mozambique). Pigeonpea has a unique place in Indian farming and India accounts for about $68 \%$ of the global production. It is the second most important pulse crop next to chickpea, covering an area of 6.66 million hectares in the world, with an average annual production of 4.85 million tons. Its average productivity is $728.5 \mathrm{~kg} \mathrm{ha}^{-1}$. The major pigeonpea growing area $(5.06 \mathrm{~m} \mathrm{ha})$ is in India with a production of 3.29 million tons with the productivity of $649.9 \mathrm{~kg} \mathrm{ha}^{-1}$ (FAO 2015). The major states in terms of area and production are Maharashtra, Uttar Pradesh, Madhya Pradesh, Karnataka, Gujarat, Andhra Pradesh, Telangana, and Bihar.

Pigeonpea named by various vernacular names viz., Guandul, poroto guandul, porotoparaguayo, sachacafé, falso café, arveja (Argentina); pigeonpea (Australia); guando (Brazil); mu dou (Chinese); pigeonpea, congo pea, red gram (English); pois cajan, poisd'Angole, ambrevade (French); poisd'angole (French-speaking West Africa); straucherbse (German); Puerto Rican bean, pigeonpea (Hawaii); red gram, tur, arhar, dal (India); frijol de árbol (Mexico); Cumandái (Paraguay); ervilha do Congo, feijão, guandu, ervilha de Angola (Portuguese); cachito (spanish); mbaazi (Swahili); duvart (Swedish); pigeonpea, angola pea (United Kingdom); quinchoncho (Venezuela).

\subsection{Origin and Geographical Distribution}

The name pigeonpea was first used in Barbados where pigeon were fed the seeds of Cajanus cajan (Plukenet 1692). Based on the wide genetic variability, Vavilov (1951) reported that India is the center of origin for cultivated pigeonpea and is also been widely cultivated in many African countries, Egypt, and a bunch of Asian countries since prehistoric times. Eastern Africa was considered as center of origin of pigeonpea by several workers owing to its occurrence in wild form (Zeven and Zhukovsky 1975). Based on the occurrence of wild relatives and diversity, van der Maesen (1980) inferred that India is the primary center of origin and Africa is the secondary center of origin for pigeonpea. It is cultivated in wide range of altitude (0-3000 m) (Ripperton and Hosaka 1942; Krause 1921) and the Latitudinal limit is $30^{\circ}$ North and South. However, the optimal being $15-20^{\circ}$ for most cultivars. Now it has been acclimatized in several tropical and subtropical countries of the world.

\subsection{Taxonomical Hierarchy}

The genus Cajanus belongs to the sub-tribe Cajaninae, tribe Phaseoleae, sub-family Papilionoideae, and family Papilionaceae. The genus Cajanus has 11 related genera [(1) Rhynchosia Lour., (2) Dunbaria W., (3) Dunbaria A., (4) Eriosema D., (5) Eriosema C., (6) Reichenb, (7) Flemingia Roxb. Ex Aiton., (8) Paracalyx Roxb. Ali, (9) Adenodolichos, (10) Baukea, and (11) Carissoa (Mallikarjuna et al. 2011)] and 32 species; (18 species are endemic to Asia, 13 to Australia, and one to West Africa De 1974; Maesen 1980).

It is postulated that the cultivated pigeonpea originated from Cajanus cajanifolius by selection for size and vigor of the plant, non-shattering pods, and larger seed size. However, the 
cultivated Cajanus cajan differs from Cajanus cajanifolius in floral morphology, pod and seed color, and 100 seed mass (Mallikarjuna et al. 2012).

Based on the genetic cross-compatibility the species of Cajanus cajan are distributed into primary gene pool (GP1), which includes the all available germplasm and $C$. cajanifolius. It is freely crossable with the cultivated types and produces fertile hybrids. While the 10 Cajanus species that are cross-compatible with $C$. cajan form the secondary gene pool (GP2), the rest of the species, which do not cross with $C$. cajan, are placed in the tertiary gene pool (GP3) (Remanandan 1990) Table 3.1.

\subsection{Botanical Descriptors}

When pigeonpea seed is sown under optimal moisture and temperature $\left(29^{\circ} \mathrm{C}-36{ }^{\circ} \mathrm{C}\right)$, the testa of the seed splits open near the micropyle on the second day. The tip of the radical elongates and emerges from the seed coat. Hypocotyl appears as an arch on the third day and continues to grow upward. The hypocotyl turns light purple. The seedling epicotyl elongates three to seven centimeters before the first trifoliate leaf emerges (Reddy 1990). Likewise, the tender seedling grows and gives rise to an erect woody shrub. The plant shows considerable variations in height, ranging from one to four meters with
Table 3.1 Gene pool system of Cajanus cajan

\begin{tabular}{|c|c|}
\hline Gene pool & Species \\
\hline GP1 & 1) C. cajan (L.) Millsp., C. cajanifolius \\
\hline GP2 & $\begin{array}{l}\text { 1) C. acutifolius (F. von Muell.) van der Maese } \\
\text { 2) C. albicans (W. \& A.) van der Maesen } \\
\text { 3) C. cajanifolius (Haines) van der Maesen } \\
\text { 4) C. lanceolatus (W. V. Fitzg.) van der Maesen } \\
\text { 5) C. latisepalus (Reynolds and Pedley) van der Maesen } \\
\text { 6) C. lineatus (W. \& A.) van der Maesen } \\
\text { 7) C. sericeus (Benth. ex Bak.) van der Maesen } \\
\text { 8) C. trinervius (D.C.) van der Maesen } \\
\text { 9) C. scarabaeoides (L.) Thouars } \\
\text { 10) C. reticulates (Dryander) F. von Muell }\end{array}$ \\
\hline GP3 & $\begin{array}{l}\text { 1) C. aromaticus van der Maesen } \\
\text { 2) C. cinereus (F. von Muell) F. von Muell } \\
\text { 3) C. crassicaulis van der Maesen } \\
\text { 4) C. crassus (Prain ex. King) van der Maesen } \\
\text { 5) C. elongatus (Benth.) van der Maesen } \\
\text { 6) C. grandiflorus (Benth. ex Bak.) van der Maesen } \\
\text { 7) C. goensis Dalz } \\
\text { 8) C. heynei (W. \& A.) van der Maesen } \\
\text { 9) C. kerstingii Harms } \\
\text { 10) C. lanceolatus (W. V. Fitzg.) van der Maese, } \\
\text { 11) C. lanuginosus van der Maesen } \\
\text { 12) C. mareebensis (Reynolds and Pedley) van der Maesen } \\
\text { 13) C. marmoratus (R. Br. ex Benth.) F. von Muell } \\
\text { 14) C. mollis (Benth.) van der Maesen } \\
\text { 15) C. niveus (Benth.) van der Maesen } \\
\text { 16) C. platycarpus (Benth.) van der Maesen } \\
\text { 17) C. pubescence (Ewart \& Morrison) van der Maesen } \\
\text { 18) C. rugosus (W. \& A.) van der Maesen } \\
\text { 19) C. villous (Benth. ex. Bak.) van der Maesen } \\
\text { 20) C. viscidus van der Maesen } \\
\text { 21) C. volubilis (Blanco) } \\
\text { 22) C. convertiflorus F. von Muell. }\end{array}$ \\
\hline
\end{tabular}




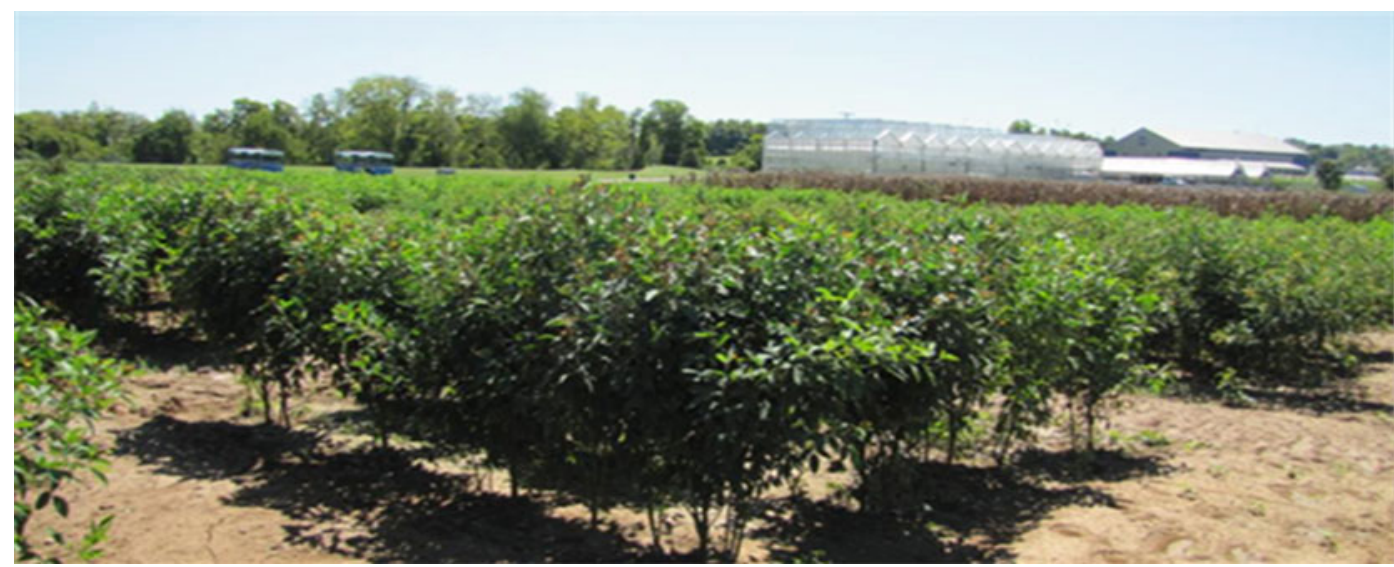

Fig. 3.1 Full-grown pigeonpea plant

taproots that extend up to two meters into the soil. In most of the types, branching begins from the sixth to the tenth node, i.e., from 15 to 20 centimeters above the ground and covers with full-fledged lush green foliage (Fig. 3.1). The comprehensive botanical description of main parts of pigeonpea plant is given below.

\subsubsection{Root System}

Under optimal conditions, root growth starts on second day after sowing. Splitting of the testa takes place near the micropyle and radicle emerges and elongation starts from the seed coat. Cambial activity results in secondary thickening (Bisen and 1981). Pigeonpea root system possesses taproot in central with numerous lateral and secondary branches. The taproot becomes thick and woody (Fig. 3.2). The length and spread of the root system is governed by the varietal characters. The erect types produce deeper and penetrating roots where as the spreading ones have shallower and spreading root system (Mahta and Dave 1931). Depending on the varieties, roots may grow deep more than two meters in the soil.

Pigeonpea is nodulated by the cowpea group of rhizobia (Brady rhizobium spp.) and forms rhizobia-symbiotic system, mainly on the upper $30 \mathrm{~cm}$ of the root system takes active participation. Nodulation starts approximately 15 days after sowing and continues up to 120 days. It declines toward pod filling stage (Kumar Rao 1990). Meristematic zone anchors the development of nodules (Bisen and Sheldrake 1981). The shape of nodules may be oval, elongate, or spherical, and the size varies from 2 to $4 \mathrm{~mm}$. The rhizobia-symbiotic systems play a significant role in improving the fertility and productivity of low nitrogen $(\mathrm{N})$ soils of arid and semi-arid regions and in turn act as a biological factory for N (Sheldrake and Narayanan 1979; Hamdi 1999).

\subsubsection{Stem}

The nodes are connected by the primary vascular tissues organized into strands, and each strand is associated with a ridge on the stem (Bisen and Sheldrake 1981). Starch accumulation will be noticed in xylem parenchyma and medullary rays during vegetative phase, and during reproductive phase, these will be mobilized for pod development (Sheldrake 1984).

\subsubsection{Branches}

The branching pattern in pigeonpea depends on genotype, habitat, and spacing of the plants. 


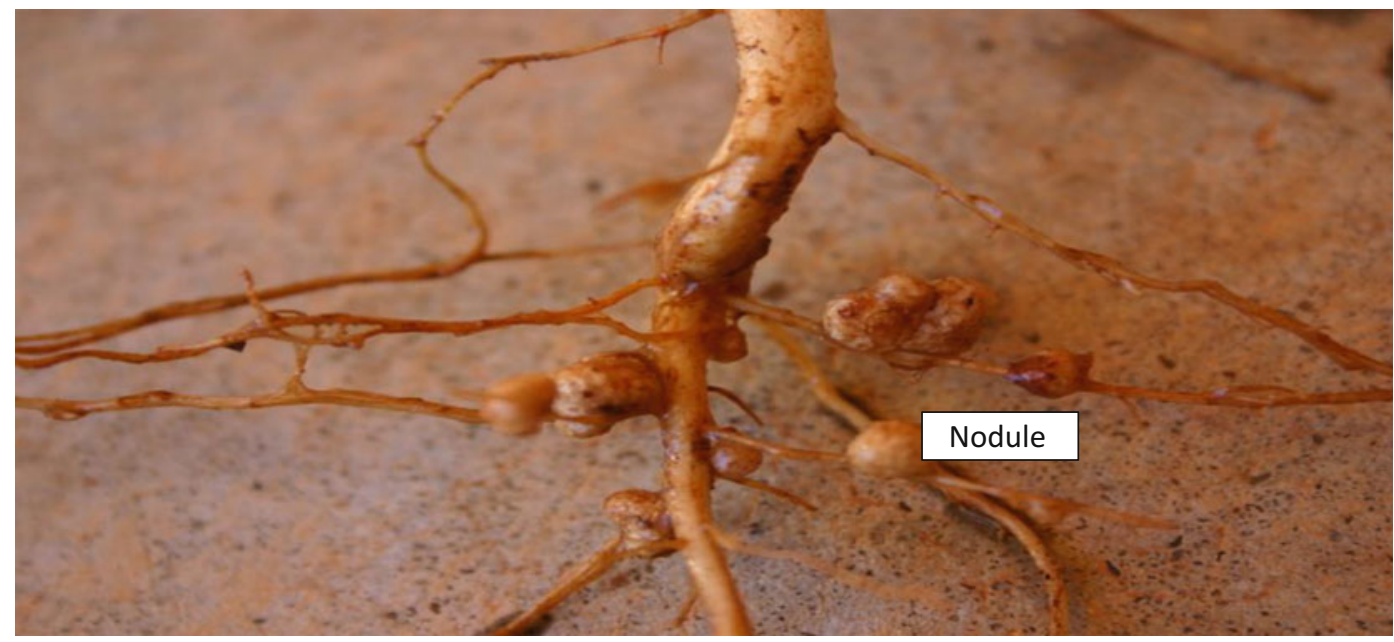

Fig. 3.2 Pigeonpea root system (a) nodules on the root branches

Wider spacing may form a bush and at narrow spacing may remain compact and upright. For agronomic purposes, pigeonpea plants can be grouped as compact (erect), semi-spreading (semi-erect), and spreading types. Based on the flowering pattern, it may be determinate or non-determinate (Fig. 3.3b). The determinate type completes the vegetative phase and then enters into the reproductive phase. In this type, the apical bud of the main shoot develops into an inflorescence, and the sequence of inflorescence production is basipetal (developing in the direction of base). The non-determinate type shows continuous vegetative and reproductive phases. In this type, the flowering starts at nodes behind the apex and proceeds both acropetally and basipetally. Another group is semi-determinate between the determinate and non-determinate types. It includes late-maturing genotypes where branching starts from different angles, but most of the pods are at the upper region of the plant.

\subsubsection{Leaves}

The leaf shape in pigeonpea varied form lanceolate to elliptical in shape. The leaflets are borne on a rachis, which is swollen at the base (pulvinus). The leaf sizes vary from 6 to $17 \mathrm{~cm}$ in length and are about the same width. The rachis varies from 2 to $4 \mathrm{~cm}$, and the terminal leaflets are $4-8 \mathrm{~cm}$ by $2-3.5 \mathrm{~cm}$. The lateral leaflets are slightly smaller. There is genetic variability in the size, shape, and color of the leaves. The leaves are pubescent with more on the lower than the upper surface. The hair types are simple or glandular. The latter are spherical and contain a yellow oily material, probably responsible for the fragrance of pigeonpea plants (Bisen and Sheldrake 1981).

\subsubsection{Inflorescence}

In most cultivars, flowers are borne on terminal or auxiliary racemes $(4-12 \mathrm{~cm})$ and are carried on a long peduncle (Fig. 3.4a). The raceme inflorescence forms a terminal panicle in non-determinate types and as corymb-shape bunch in the determinate types. These are grouped together at the end of branches in late types and distributed along the branches in early, medium, and indeterminate types (Sharma and Green 1980). The number of racemes plant ${ }^{-1}$ in the pigeonpea world collections ranged from 6 to 915 (Remanandan et al, 1988). Flowering proceeds acropetally (in the direction of apex) both within the raceme and on the branch. 
Fig. 3.3 a Woody stem of pigeonpea. b Different growth habit types in pigeonpea.

c Trifoliate leaf of pigeonpea

(a)

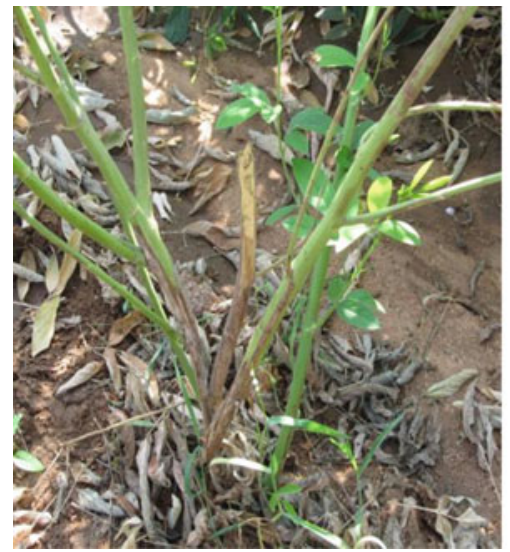

Woody green stem

(b)

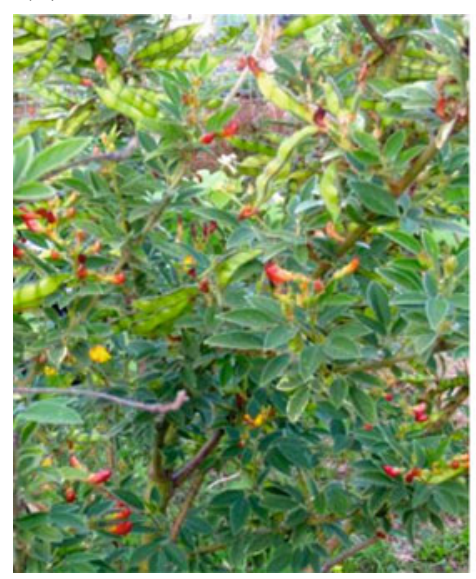

(c)

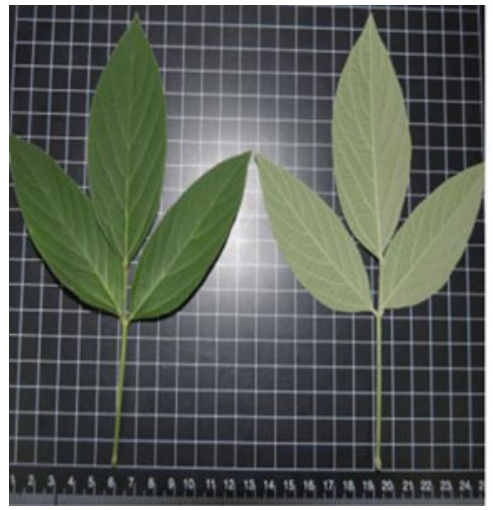

Lanceolate leaf

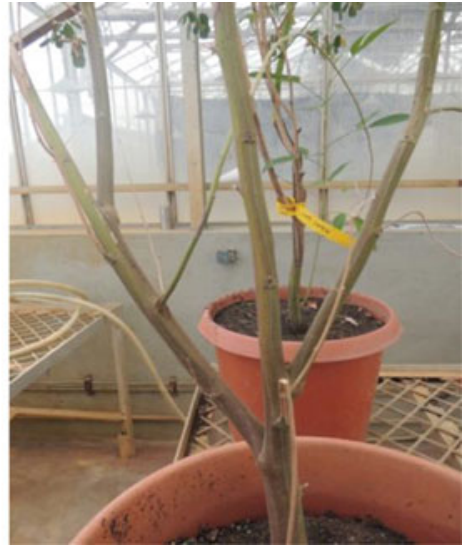

Woody purple stem

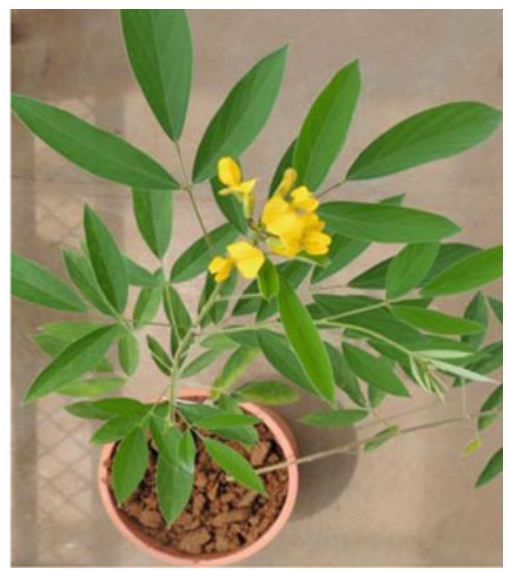

Determinate branching

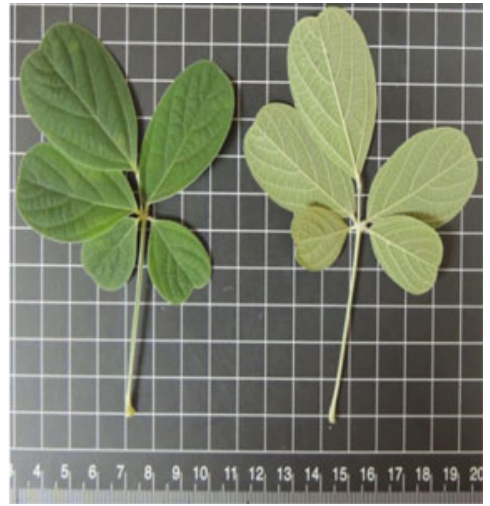

Obcordate leaf 
(a)

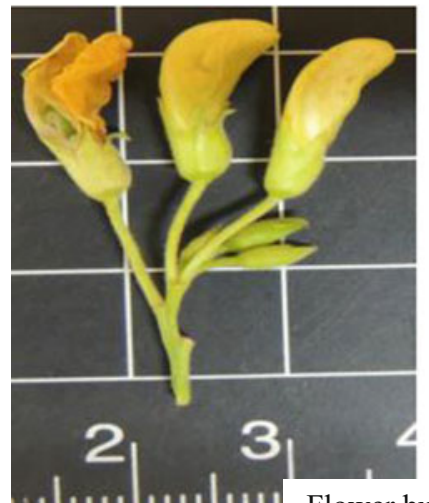

(b)

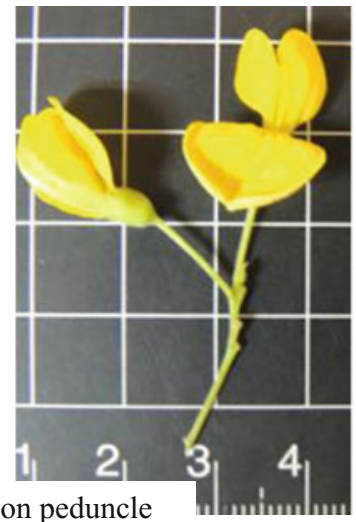

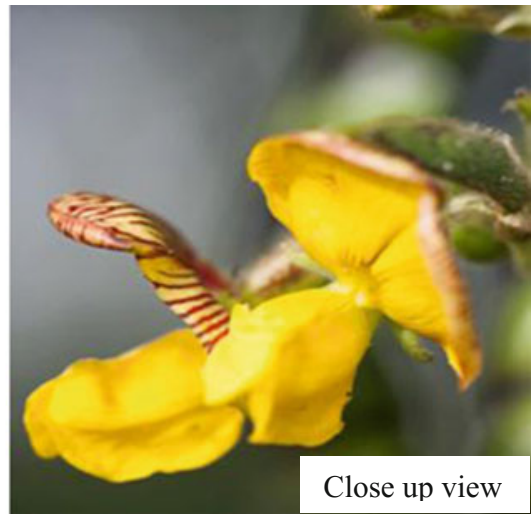

(c)

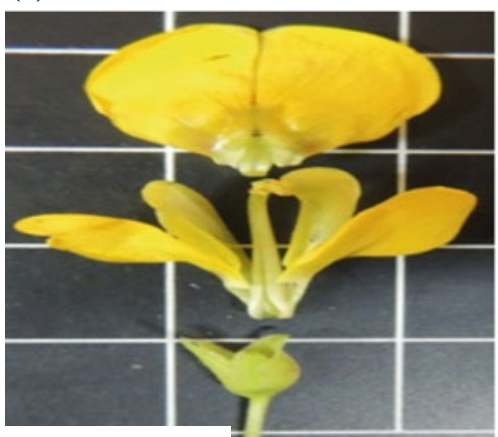

Full open Flower
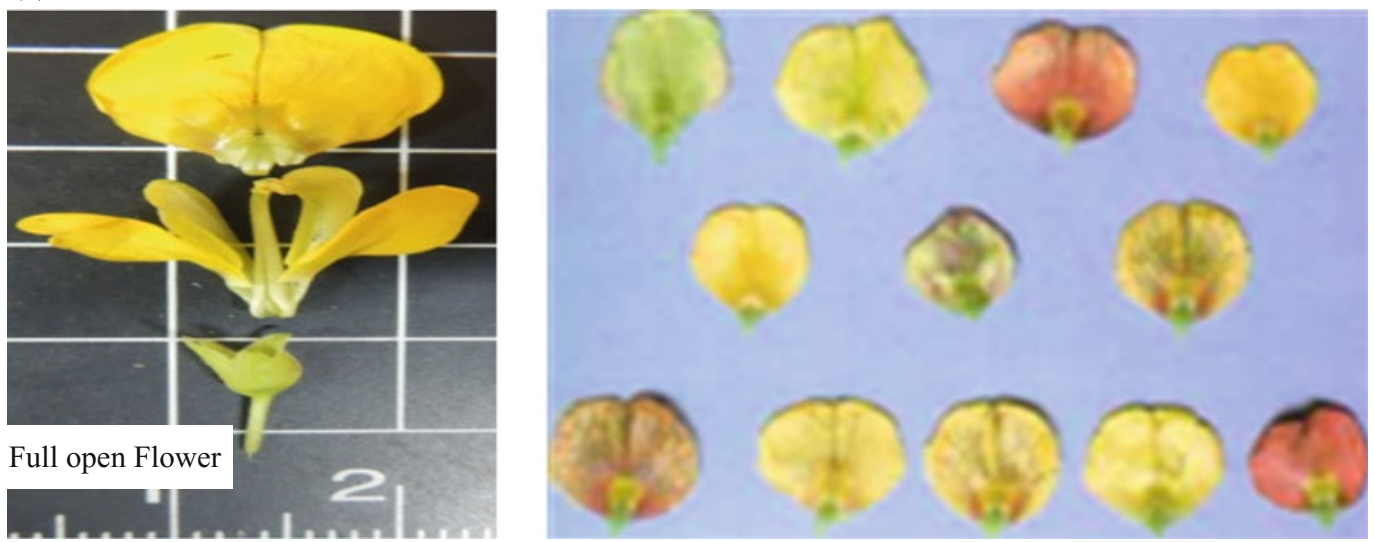

(d)

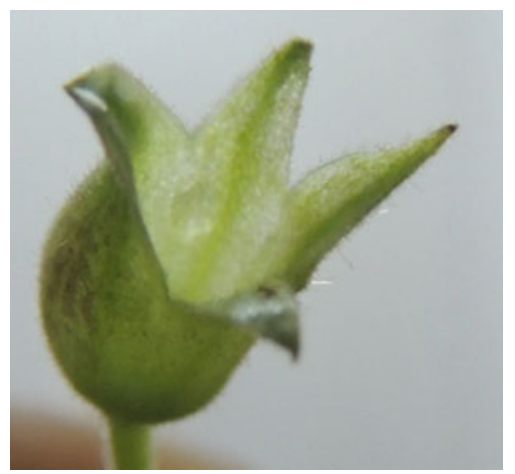

Bract of pigeonpea

(e)

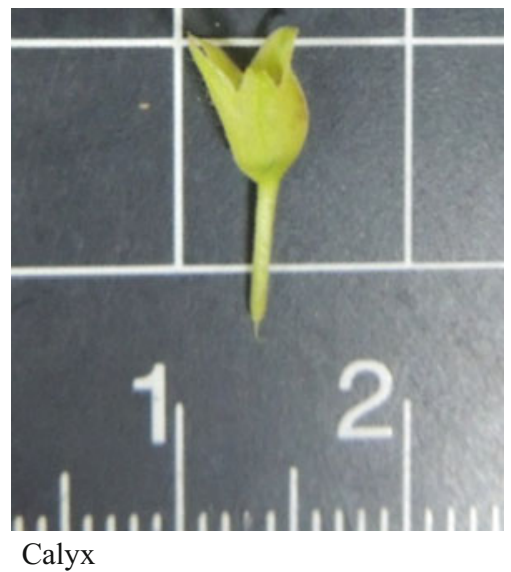

Fig. 3.4 a and $\mathbf{b}$ Flower buds and Full bloom flower of pigeonpea. $\mathbf{c}$ Dissected flower and Streak pattern of standard petal. d Bract of pigeonpea. e Calyx 


\subsubsection{Flowers}

The flowers (Fig. 3.4a, b) are clustered at the top of the peduncle. The peduncles are 1-8 cm long. Flowers are normally yellow, however; the main color of the petals could be ivory (green-yellow group 1), light yellow (yellow group 6D), yellow (yellow-orange group 14A), and orange-yellow (orange-red group 31A). Color of streaks on dorsal side of the vexillum (flag) and second color of the wings and keel petals could be red (red group 45 A) or purple (grayed-purple group 186A) (Royal Horticultural Society). The streaks pattern of second color on the dorsal side of the flag (standard petal) ranges from no/sparse streaks to dense/uniform coverage of streaks (Fig. 3.4c).

The bracts (Fig. 3.4d) are small with a thick middle nerve. They are ovate-lanceolate with hairy margins and curved inward to form a boat-like structure to enclose one-to-three young lateral buds. The pedicel is thin, $5-15 \mathrm{~mm}$ long, and covered with hair. The flowers are mostly yellow and papilionaceous or completely bisexual and zygomorphic (Sundaraj and Thulasidas 1980). The calyx is gamosepalous with five lobes. The calyx tube is campanulate (bell-shaped) with nerved teeth. The upper two teeth are sub-connate. The lower three are free and spreading (Fig. 3.4e). The upper lobes are paired, free or partly free, and the lower one is the longest.

Corolla: The corolla is zygomorphic (yoke-shaped flowers symmetrical about one plane) and bright yellow. The petals are imbricate and of three prominent types; the standard, wings, and a keel. The standard is broad, large, auricled, and erect (Fig. 3.5a). The wings are obliquely obovate with an incurved claw (Fig. 3.5b). The keel petals are obtuse (round) incurved and boat shaped (Fig. 3.5c). The keel covers the androecium (stamens) and gynoecium (female organs) of the flower.

Androecium: The two halves of the anthers are joined by a relatively large, sterile connective tube that is basi fixed. The anthers are light or dark yellow, dorsi fixed. Of the 10 stamens, four have short filaments and six, including a posterior one, have long filaments. The short anthers have blunt lobes and the long ones pointed lobes.
The pollen produced by short stamens is generally used for self-fertilization (Bahadur et al. 1981).

Gynoecium: The ovary is superior, subsessile, flattened dorsoventrally along with style (Fig. 3.5e). It has a very short stalk, densely pubescent, and glandular punctate (dotted or pitted) with two to nine ovules, marginal placentation, monocarpellary, and unilocular. The style is long, filiform, upturned beyond the middle region, and glabrous. It is attached to a thickened, incurved, and capitate (swollen) stigma.

\subsection{Pollination}

Pigeonpea is an often cross-pollinated crop ranges from 3 to $40 \%$. In a fully developed bud, anthers surround the stigma and dehisce a day before the flower opens. Anthesis in pigeonpea starts from $06.00 \mathrm{~h}$ and continues till $16.00 \mathrm{~h}$. The peak anthesis period recorded is between 09.00 and $10.00 \mathrm{~h}$ (Sharma and Green 1980). The duration of flower opening also depends on the weather and environment. This varies from 6 to $36 \mathrm{~h}$. Fertilization occurs on the day of pollination.

\subsection{Pod/Fruit Development}

The fruit of pigeonpea is a pod. During the first week of anthesis, the endosperm undergoes rapid development. The nuclei take up a parietal position, forming a large vacuole in the center of the embryo sac. The embryo sac elongates at the chalazal region and forms a haustorium. The haustorium penetrates into the nucellar tissue. This is instrumental in absorbing food material that is used by the developing embryo. In the cotyledons, synthesis of starch and protein starts about 17 days after pollination and continues for 14 days (Sehgal et al. 1987). In each raceme, 1-5 pods may mature, rarely up to 10 . Pods are of various colors (Fig. 3.6); green, purple, dark purple, or mixed green and purple. The seeds per pod range from two to seven, and sometimes up 


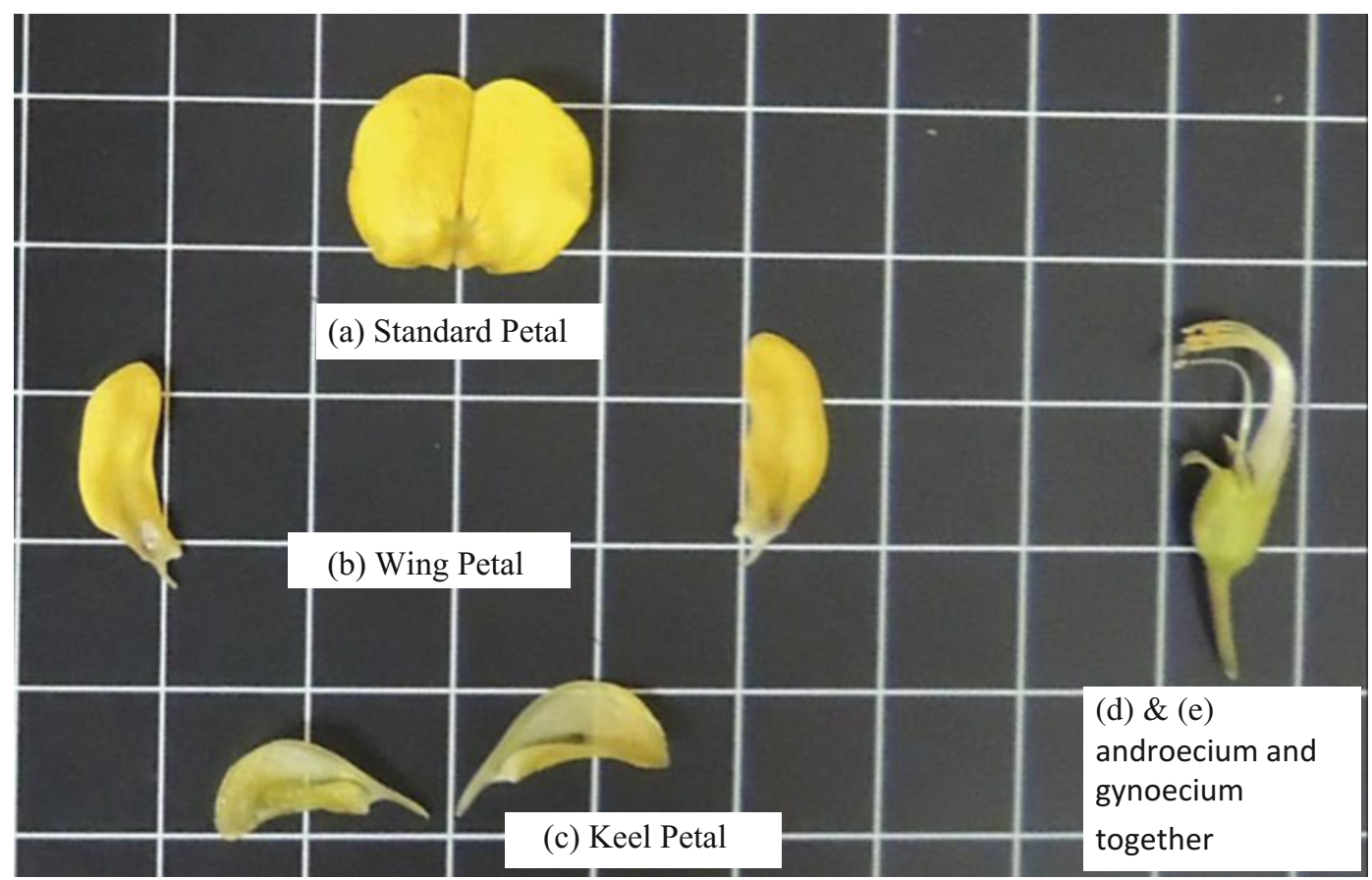

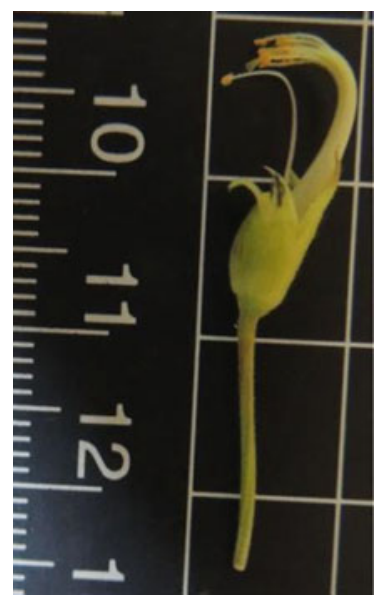

(d) \& (e) Close up view of androecium and gynoecium

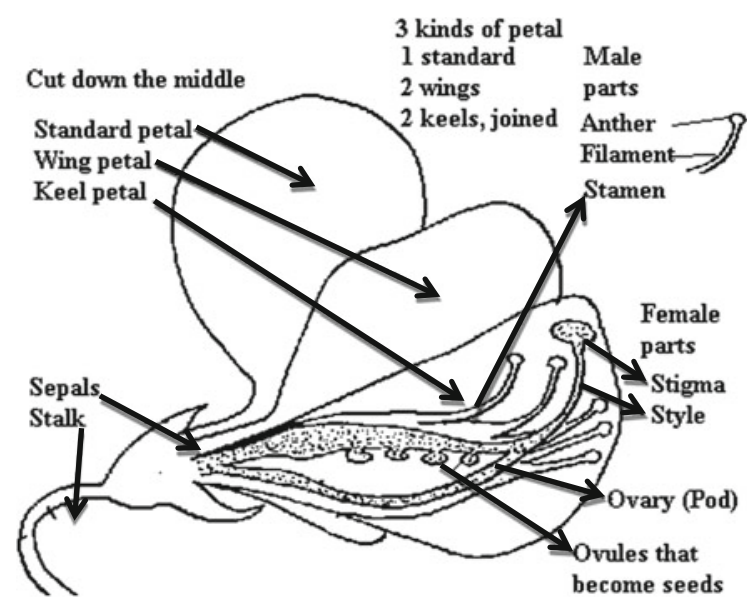

(f) Schematic detail view of androecium and gynoecium

Fig. 3.5 a Standard Petal. b Wing Petal. c Keel Petal. d and e androecium and gynoecium together. d and e Close up view of androecium and gynoecium. f Schematic detail view of androecium and gynoecium

to nine. The seeds are in separate locules, and the cross-walls develop during the first week after fertilization. The pod wall develops more rapidly than the young seeds. Seed development is visible 7 days after pollination. A pod is formed
15-20 days after fertilization. Seeds reach physiological maturity in 30 days and are ready for harvest at lower moisture content in 40 days (Rao and Rao 1974). There is little or no shattering of mature pods in the field. 
Fig. 3.6 Pigeonpea pods are of various colors and sizes

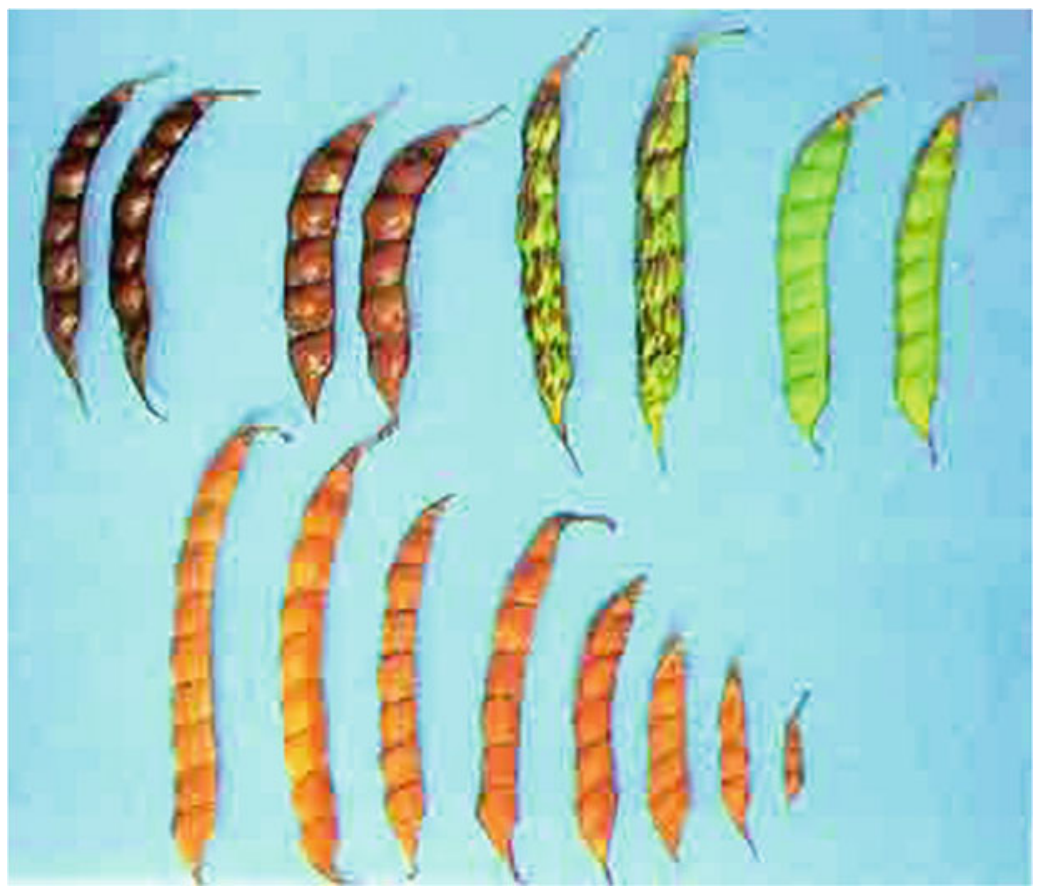

\subsection{Seeds}

Seeds are round or lens shaped, the color of the seed coat varies from dirty white to silver white, light brown to chestnut brown, dark mottled brown and pinkish black, and the cotyledons are yellow colored (Fig. 3.7). The seed is orthodox and can be stored for long term under frozen condition. The seed coat color is relatively trivial character, but it is a consistent feature of pigeonpea evolution that lighter colored testae have consistently been favored in selection. This is frequently the case even when the testa is removed as in the preparation of split peas.

\subsection{Chemotaxonomy and Biochemistry}

The most productive chemotaxonomic studies carried out to date are those of Ladizinsky and Hamel (1980) and Singh et al. (1981) using electrophoresis. The seed protein separation patterns produced was generally similar in Cajanus and former Atylosia species, confirming congeneric. It was also observed that species which had been successfully crossed with pigeonpea had more closely similar patterns than those which failed to cross. Variation within the pigeonpea was also found to be less than between itself and $C$. cajanifolius, the most similar wild species.

Pigeonpea seeds are made up of $85 \%$ cotyledons, $14 \%$ seed coat, and about $1 \%$ embryo, and contain a variety of dietary nutrients (Table 3.2). The cotyledons are rich in carbohydrates $(66.7 \%)$ while a major proportion (about 50\%) of seed protein is located in embryo. About one-third of seed coat is made up of fiber. The quantities of important sulfur-containing amino acids such as methionine and cystine range around $1 \%$, and they are present in cotyledons and embryo, while calcium is predominantly present in seed coat and embryo (Saxena et al. 2010). In the review of Toms and Western (1971), its seed is reported as being free of measurable hemagglutinating activity; Liener (1982), in a review of literature 
Fig. 3.7 Different colors and sizes of pigeonpea seeds

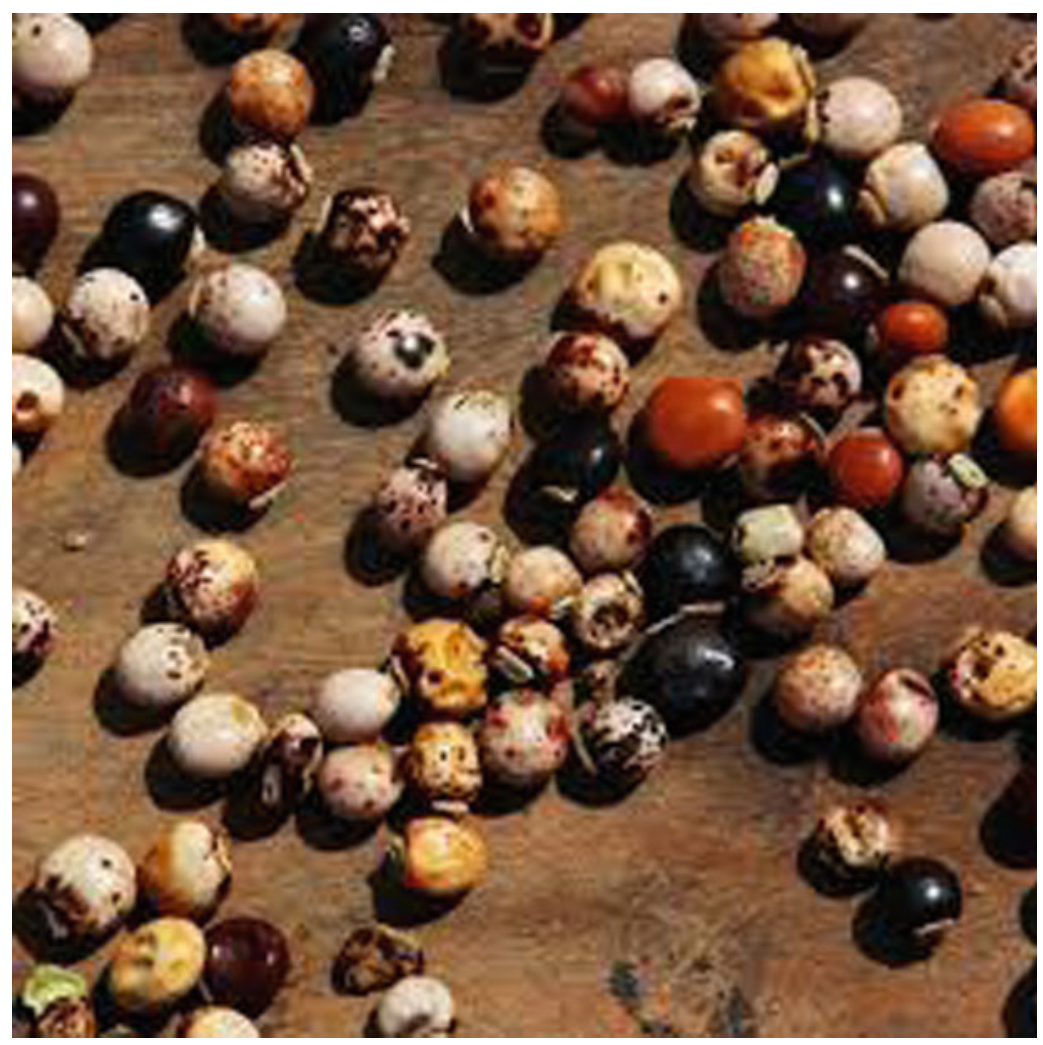

Table 3.2 Nutrient composition in green seed, mature seed, and dal of pigeonpea

\begin{tabular}{l|l|l|l}
\hline Constituent/cooking time & Green seed & Mature seed & Dal \\
\hline Protein (\%) & 21.0 & 18.8 & 24.6 \\
\hline Protein digestibility (\%) & 66.8 & 58.5 & 60.5 \\
\hline Trypsin inhibitor (units $\mathrm{mg}^{-1}$ ) & 2.8 & 9.9 & 13.5 \\
\hline Soluble sugars (\%) & 5.1 & 3.1 & 5.2 \\
\hline $\begin{array}{l}\text { Flatulence factors } \\
\left(\mathrm{g} 100 \mathrm{~g}^{-1} \text { soluble sugar) }\right.\end{array}$ & 10.3 & 53.5 & - \\
\hline Crude fiber (\%) & 8.2 & 6.6 & 1.2 \\
\hline Fat $(\%)$ & 2.3 & 1.9 & 1.6 \\
\hline
\end{tabular}

Minerals and trace elements ( $m g 100 \mathrm{~g}^{-1}$ )

\begin{tabular}{l|l|l|l}
\hline Calcium & 94.6 & 120.8 & 16.3 \\
\hline Magnesium & 113.7 & 122.0 & 78.9 \\
\hline Copper & 1.4 & 1.3 & 1.3 \\
\hline Iron & 4.6 & 3.9 & 2.9 \\
\hline Zinc & 2.5 & 2.3 & 3.0 \\
\hline Cooking time (min) & 13 & 53 & 18
\end{tabular}

(Table re-rewritten from Saxena et al. 2010) 
on legume seed toxins and anti-metabolites, mentions the pigeonpea solely on account of a very low cyanide content.

\subsection{Ecological Requirement}

Cajanus cajan is hard woody shrub, widely adaptable to a range of soil types, temperature and rainfall. Pigeonpea can tolerate the temperatures as high as $35^{\circ} \mathrm{C}$. However, it can be killed by heavy frost. An average annual rainfall between 600 and $1000 \mathrm{~mm}$ is most suitable. Perhaps, it can be grown in humid areas, even over $2500 \mathrm{~mm}$ of rainfall and is renowned for its drought tolerance. It gives economic yield of seeds in areas where rainfall averages about $400 \mathrm{~mm}$ annually. Although it cannot withstand waterlogging, it can be grown in a wide range of soils, as it tolerates low fertility. Some cultivars are tolerant of salinity and aluminum toxicity. A pH range of $4.5-8.4$ is tolerated.

\subsection{Conclusion}

Cajanus cajan is the only cultivated species domesticated from the genus Cajanus. It is the unique jewel in rain-fed cropping systems (as sole and intercrop) across the globe. Rich source of protein complements well for a balanced diet with cereals. Versatile use of pigeonpea for human livelihood brought up it as a crop of main land. Pigeonpea is a 'Kalpavriksha' for arid and semi-arid region farmers of the world. Therefore, knowing detailed botany of the crop helps the researchers to modify according to the needs of the future.

\section{References}

Bahadur B, Rao MM, Rao KL (1981) Studies on dimorphic stamens and pollen (SEM) and its possible role in pollination biology of Cajanus cajan Millsp. Indian J Botany 4:122-129

Bisen SS, Sheldrake AR (1981) The anatomy of the pigeonpea. Research bulletin no. 5. Patancheru, A.
P. 502324, India: International Crops Research Institute for the Semi-Arid Tropics, p 24

De DN (1974) Pigeonpea. In: Hutchinson J (ed) Evolutionary studies in world crops: diversity and change in the indian subcontinent. Cambridge University Press, London, UK, pp 79-87

Food and Agriculture Organization (2015) http://faostat. fao.org/database

Hamdi HZ (1999) Rhizobium-legume symbiosis and nitrogen fixation under severe conditions and in an arid climate. Microbiol Mol Biol Rev 63(4):968-989

Krauss FG (1921) The pigeonpea (Cajanus indicus): its culture and utilization in Hawaii. University of Hawaii Agri. Expt. Station Bulletin 46, Honolulu, Hawaii, USA

Kumar Rao JVDK (1990) Pigeonpea: nitrogen fixation. In: Nene YL, Hall SD, Sheila VK (Eds) The pigeonpea. CAB International, Wallingford, UK, pp 233-256

Ladizinsky G, Hamel A (1980) Seed protein profiles of pigeonpea (Cajanus cajan) and some Atylosia species. Euphytica 29:313-317

Liener IE (1982) Toxic constituents in legumes, in chemistry and biochemistry of legumes, Oxford and IBH Publishing Co., New Delhi, pp 217-257

Mahta DN, Dave BB (1931) Studies in Cajanus indicus. Memoirs Dept Agric India (Botanic Ser) 19:1-25

Mallikarjuna N, Saxena KB, Lakshmi J, Varshney R, Senthilvel S, Sandhya Rani S, Jadhav DR (2011) Differences between Cajanus cajan (L.) Millspaugh and $C$. cajanifolius (Haines) van der Maesen, the progenitor species of pigeonpea. Genet Resour Crop Evol doi:10.1007/s10722-011-9691-8

Mallikarjuna N, Saxena KB, Laxmi J, Varshney R, Srikanth S, Jadhav D (2012) Differences between Cajanus cajan and $C$. cajanifolius, the progenitor species of pigeonpea. Genet Resour Crop Evol 59:411-417

Plukenet L (1692) Phytographia 3, Table 213, Figure 3

Raddy LJ (1990) Pigeonpea: morphology. In: Nene YL, Hall SD, Sheila VK (Eds) The pigeonpea. CAB International, Wallingford, UK, pp 47-88

Rao MKV, Rao RG (1974) Gibberellin like substance in developing and germinating seeds of pigeonpea. Indian J Plant Physiol 17(1/2):65-72

Remanandan P (1990) Pigeonpea: genetic resources. In: Nene YL, Hall SD, Sheila VK (Eds), The Pigeonpea. CAB International, Wallingford, UK, pp, 89-115

Remanandan P, Sastry DVSSR, Mengesha MH (1988) ICRISAT pigeonpea germplasm catalogue: evaluation and analysis. Patancheru, A.P. 502324, India: International Crops Research Institute for the Semi-Arid Tropics, p 95

Ripperton JC, Hosaka EY (1942) Vegetation zones of Hawaii. Hawaii Agricultural Experiment Station, University of Hawaii, Honolulu (HI), pp 60 (Bulletin No. 89)

Royal Horticultural Society (Great Britain). Extracts from the proceedings of the Royal Horticultural Society, (http://www.biodiversitylibrary.org/bibliography/ 79650) 
Saxena KB, Kumar RV, Sultana R (2010) Quality nutrition through pigeonpea - a review. Crop Sci 2 (11):1335-1344

Sehgal CB, Gandhi V, Varma B (1987) Histological and histochemical studies on the cotyledons of some legumes. II. Reserve metabolites during seed development. Cytologia 52:847-858

Singh U, Jambunathan R, Gurtu S (1981) Seed protein fractions and amino acids composition of some wild species of Pigeon pea. J Food Sci Technol 18:83-85

Sharma D, Green JM (1980) Pigeonpea. In: Fehr WR, Hadley HH (Eds) Hybridization of crop plants. American Society of Agronomy and Crop Science Society of America, Madison, WI, USA, pp 471-481

Sheldrake AR (1984) Pigeonpea. In: Goldsworth PR, Fisher NM (Eds) The physiology of tropical field crops. John Wiley \& Co, Chichester, USA, pp 385-417

Sheldrake AR, Narayanan A (1979) Growth development and nutrient up take in pigeonpea (Cajanus cajan). J Agric Sci (UK) 92:513-526
Sundaraj DD, Thulasidas G (1980) Botany of field crops. The Macmillan Company of India Ltd, New Delhi, p 496

Toms GC, Western A (1971) Phytohaemagglutins. In: Harborne JB, Boulter D and Turner BL (Eds) Chemotaxonomy of the Leguminosae. Academic Press, London, pp 367-462

van der Maesen LJG (1980) India is the native home of pigeonpea. In: Arends JC, Boelema G, de Groot CT, Leeuwenberg AJM, Veenman $\mathrm{H}$, Zonen BV (Eds) Libergratulatorius in honorem H.C.D. de Wit landbouwhoge school, Miscellaneous paper no. 19, Wageningen, Netherlands, pp 257-262

Vavilov NI (1951) The origin, variation, immunity and breeding of cultivated plants. Chronica Botanica 13 $(1-6): 1-366$

Zeven AC, Zhukovsky PM (1975) Dictionary of cultivated plants. In: Huxby J (ed) The new systematics. Oxford University, London, UK, pp 549-566 